\title{
Female sexual maturation and reproduction after prepubertal exposure to estrogens and endocrine disrupting chemicals: A review of rodent and human data
}

\author{
G. Rasier ${ }^{\mathrm{a}}$, J. Toppari ${ }^{\mathrm{b}}$, A.-S. Parent ${ }^{\mathrm{a}}$, J.-P. Bourguignon ${ }^{\mathrm{a}}$ \\ ${ }^{a}$ Developmental Neuroendocrinology Unit, Center for Cellular and Molecular Neurobiology, University of Liège, University Hospital \\ Center, B36, +1, B-4000 Liège (Sart-Tilman), Belgium \\ ${ }^{\mathrm{b}}$ Departments of Physiology and Pediatrics, University of Turku, FI-20520 Turku, Finland
}

\begin{abstract}
Natural hormones and some synthetic chemicals spread into our surrounding environment share the capacity to interact with hormone action and metabolism. Exposure to such compounds can cause a variety of developmental and reproductive detrimental abnormalities in wildlife species and, potentially, in human. Many experimental and epidemiological data have reported that exposure of the developing fetus or neonate to environmentally relevant concentrations of some among these endocrine disrupters induces morphological, biochemical and/or physiological disorders in brain and reproductive organs, by interfering with the hormone actions. The impact of such exposures on the hypothalamic-pituitary-gonadal axis and subsequent sexual maturation is the subject of the present review. We will highlight epidemiological human studies and the effects of early exposure during gestational, perinatal or postnatal life in female rodents.
\end{abstract}

Keywords: female puberty ; endocrine disrupters

\section{Introduction}

Since the 1990s, the plausibility that some environmental and industrial chemicals could cause a number of disorders in hormonally regulated biological systems and, ultimately, affect harmfully the human, has preoccupied biologists, toxicologists and epidemiologists. In addition, the time of exposure during development is a clue since evidence has accumulated that disturbances of the (very) early life environment have an impact on the child and, further, adult health. Those adverse substances, which are widespread in our surrounding environment, are called "endocrine disrupting chemicals (EDCs)" or "endocrine disrupters". They interfere with the endocrine system and thus may affect the development and/or reproduction in many animal species (Colborn et al., 1993; Marshall, 1993; Toppari et al., 1996). They consist of two groups: natural substances such as animal hormones and phytoestrogens, and man-made industrial chemicals, including pesticides, phenol derivatives, phthalates, dioxins,....

Many EDCs have an estrogenic activity. Mechanistic experiments indicate that these chemicals interact with the estrogen receptors (ERs) and stimulate or inhibit some sensitive cell types in a number of different ways (Ferguson et al., 2000; Gutendorf and Westendorf, 2001; Holmes et al., 2004). There are also many compounds which exhibit other effects, including antiestrogenic, androgenic or antiandrogenic. The compounds may act on the receptor level or influence the synthesis and metabolism of hormones, receptors and transcription factors. They can affect the hypothalamic-pituitary-gonadal (HPG) axis, with consequences on sexual development and functioning (Clark et al., 1998; Gray, 1998; Toppari and Skakkebaek, 1998; Takeyoshi et al., 2002; Toppari, 2002).

In this review, we will briefly describe the processes of sexual differentiation and maturation in the rodent. The mechanisms of central versus peripheral puberty will be opposed and the reasons for using the immature female rodent to study EDC effects will be discussed in the light of our previous clinical observations. We will then review the data obtained in rodents and humans with different chemicals.

\section{Comparative sexual differentiation and maturation in female rodents and humans}

The reproductive system of female rodents (primarily rats and mice) shares a number of characteristics with the human. Consequently, these animals have been extensively used in biological research and are routinely employed in laboratory studies designed to elucidate the mammalian mechanisms of reproductive development and functions. The murine female puberty is a transitional process which encompasses vaginal opening (VO) and first ovulation (Fig. 1A). VO is the initial sign of the estrogenic rise that accompanies the onset of puberty and first ovulation followed by estrous cyclicity as the initial sign of a central drive of ovarian activity (Ramirez and Sawyer, 1965). The corresponding events in the human are the onset of breast development (stage B2) and 
menarche, respectively. In the rat, the mean age at VO varies among the strains and with raising conditions. It usually takes place around 35 days. The mean interval between VO and first estrus is $4.2 \pm 1.1$ days. In the laboratory rat, sexual maturation starts very early in life, when compared with the human female on a time scale determined by the lifespan (Fig. 1A and B) and the individual variations in timing of pubertal events are comparatively much less than observed in the human. The occurrence of the first ovulatory episode is an ovarian response to a massive secretory surge of the gonadotrophins (follicle-stimulating hormone and luteinizing hormone, FSH and LH). In the rodent, programming of the central mechanism of ovulation takes place between the last week of prenatal life and the first week of postnatal life (Naftolin, 1994). Early exposure to sex steroids causes disturbances in that process (Matagne et al., 2004) whereas, in the human female, there is no convincing evidence of a similar mechanism (Grumbach and Styne, 2003).

Fig. 1. Schematic representation of the main pubertal events in the female. Comparison between laboratory rat (A) and human (B) based on a similar lifespan time scale.

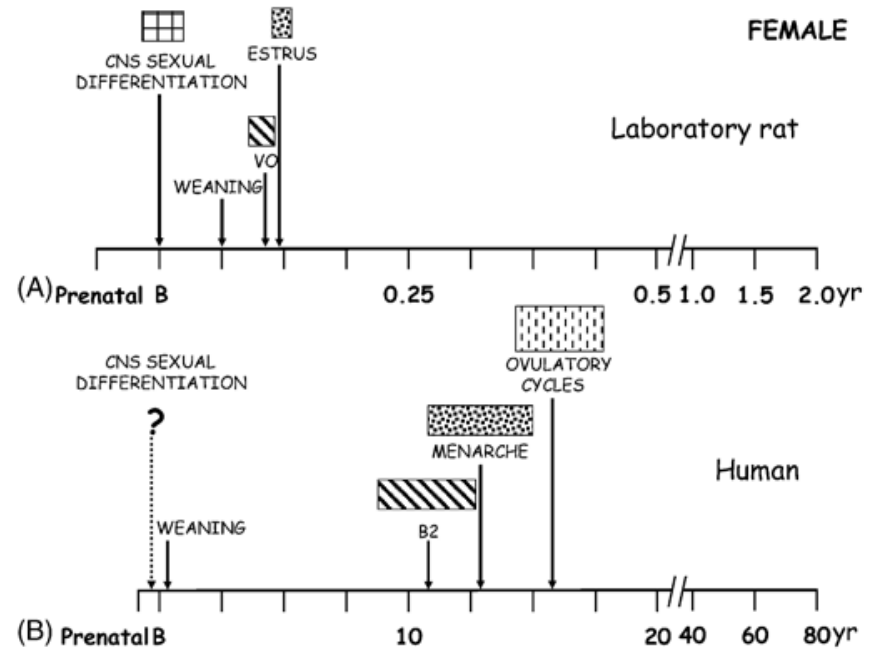

\section{Central versus peripheral puberty}

The mechanism of onset of female puberty has been reviewed recently by Ojeda and Terasawa (2002). There are several endpoints that involve two different pathophysiologic mechanisms. In central puberty, estrogens are produced following ovarian stimulation by the HP system (Fig. 2A). In peripheral puberty, endogenous estrogens are produced in a gonadotrophin-independent manner (Fig. 2B) or they come from exogenous administrations. The study of sex steroid sensitive tissues such as uterus, vagina and breasts or anogenital distance (AGD) for estrogenic effects (e.g. VO) may provide an insight into central as well as peripheral puberty. The study of pituitary gonadotrophins and hypothalamic gonadotrophin-releasing hormone $(\mathrm{GnRH})$ provides information on the central components and the possible effects of steroids and EDCs at those levels. In a previous study involving some among us, central sexual precocity was reported to occur very frequently in foreign migrating girls, as a possible consequence of early and temporary exposure to dichlorodiphenyltrichloroethane (DDT) (Krstevska-Konstantinova et al., 2001; Parent et al., 2003). As illustrated schematically in Fig. 2C and D, it was hypothesized that, during exposure to an estrogenic EDC, hypothalamic maturation could be stimulated while pituitary gonadotrophins are inhibited through a negative feedback effect. This prevents any manifestation of central maturation and only peripheral puberty can thus be observed (Fig. 2C). Migration causes withdrawal from the EDC and the consequent pituitary inhibition disappears, allowing the hypothalamic maturation to turn on the pituitary-ovarian cascade of pubertal events, i.e. central puberty (Fig. 2D). 
Fig. 2. Schematic illustration of the hypothalamic-pituitary-gonadal (HPG) axis function in different conditions: stimulation in physiological or precocious central puberty $(A)$, inhibition in peripheral puberty due to steroids of extra-gonadal origin (B), hypothalamic stimulation and PG inhibition in the presence of an estrogenic EDC $(C)$ and HPG stimulation after withdrawal from the EDC $(D)$.

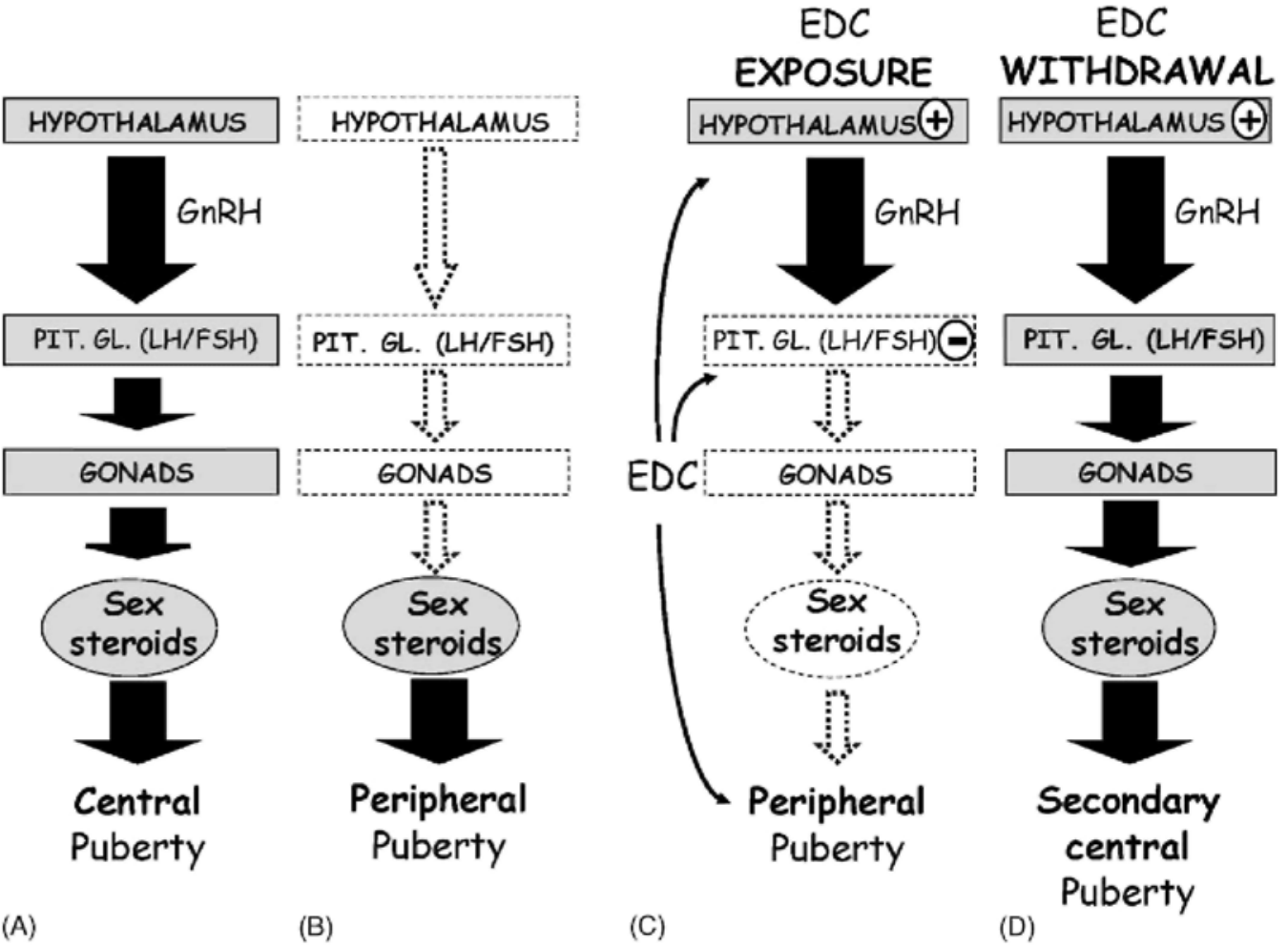

\section{Prepubertal exposure to EDCs: female study endpoints in rodents}

In consistency with the above observations, we were interested in delineating the central effects of sex steroid and EDC on the HP mechanism of puberty. In the rat, GnRH can be detected in the hypothalamus by the gestation day (GD) 12 and the levels of this decapeptide gradually increase until a few days after the parturition (Aubert et al., 1985). A steep rise takes place through the second suckling week, followed by a further increase that continues until puberty (Chiappa and Fink, 1977). Moore and Wray (2000) indicated that GnRH neurons in the olfactory placode can already exhibit neuroendocrine secretory properties. Indeed, embryonic GnRH neurons from nasal expiants were capable of synthesizing, secreting and rapidly replenishing stores of GnRH peptide, and Wetsel et al. (1991) showed that the immature GnRH-secreting GT1-7 cell line secreted pro-GnRH. The postnatal ontogeny of frequency of pulsatile GnRH secretion in rat hypothalamic expiants revealed a developmental acceleration before 21 days of age (Bourguignon and Franchimont, 1984) while others found such an increase to occur later in vivo (Sisk et al., 2001; Harris and Levine, 2003). Data from Ford and Ebling (2000) showed that GnRH transcript level increased markedly between birth and postnatal day (PND) 12 and that endogenous glutamatergic signal played a role as potential regulator during development, allowing maintenance of a sufficient level in adulthood (Gore et al., 1999). These data indicate that GnRH synthesis is not a rate-limiting factor for the onset of puberty. Such a concept is in agreement with our observation that an adult pattern of pulsatile GnRH secretion from neonatal hypothalamic expiants can be obtained during intermittent stimulation by glutamate (Parent et al., 2005). Indeed, an increase in glutamatergic input to GnRH neurons plays a role in the elevated GnRH release and gene expression that occurs at the initiation of puberty (Gore et al., 1996). Then, the responsiveness of the GnRH neurons to neurotransmitter stimulations becomes enhanced, as a potent inhibitory influence of estradiol (E2) declines (Docke et al., 1981; Ojeda et al., 1986). The effects of steroids or some EDCs on such endpoints will be discussed below. In our laboratory, the developmental increase in frequency of pulsatile GnRH secretion in vitro has been shown to be particularly sensitive to sex steroids administered in vitro or in vivo around the age of 10-15 days (Matagne et al., 2004). Thus, the immature female rat provides a condition with high sensitivity of the HP unit to the inhibitory and stimulatory effects of estrogens.

In the human, preliminary observations indicate that onset of puberty can be vulnerable to environmental effects on the neuroendocrine processes, culminating in the emergence of disorders in mature reproductive functions (Parent et al., 2003). The pubertal alterations can be either an advancement or a delay of maturation, maybe 
depending on the chemical and the conditions of the insult (age at exposure, doses, mixture effects, gender). In experimental conditions, the sensitivity to these effects can vary among species. Here, we will focus on the influence of several types of EDCs on the HPG axis after prepubertal (gestational, perinatal and/or postnatal) exposure of the female rodent in vivo. More specifically, we will address the impact on sexual maturation and the reproductive tract after such exposures, with emphasis on the comparative effects of low or high doses, prolonged or acute exposure and subcutaneous (s.c.) or oral administration. EDC impact using in vitro hypothalamic or pituitary expiant and GnRH neuronal cell line models will also be discussed.

\section{Effects of different EDCs on sexual maturation and reproductive functions}

\subsection{E2, a reference natural estrogen}

E2 is the main natural estrogenic hormone in the female. It is principally secreted by the ovaries and is known to exert a vast number of endocrine and metabolic functions in the mammals, notably on the HP unit during development and on the estrous cyclic activity. It was shown that the administration of ovarian steroids (E2 and progesterone) in ovariectomized rats not only influenced the release of hypothalamic GnRH but also the processing of GnRH precursor forms (Drouva et al., 1986). These effects involve a negative (inhibitory) feedback control of GnRH and the pituitary gonadotrophins which is very potent in the immature individual (Grumbach and Styne, 2003). In the mature female, a so-called positive (stimulating) feedback is also exerted by E2 and leads to the preovulatory GnRH and gonadotrophin (FSH and LH) surge (Levine, 1997; Terasawa, 2001).

Table 1 Data on effects of estradiol on several hypothalamic-pituitary-ovarian outcomes

\begin{tabular}{|c|c|c|c|c|c|c|c|}
\hline $\begin{array}{l}\text { Age at } \\
\text { treatment }\end{array}$ & $\begin{array}{l}\text { Dose } \\
\text { (per kg day) }\end{array}$ & $\mathrm{VO}$ & 1 st estrus & Cyclicity & HP axis & $\begin{array}{l}\text { Uterus } \\
\text { weight }\end{array}$ & Ref. \\
\hline PND 1-10 & $10 \mu \mathrm{g}$ & Advanced & & $\begin{array}{l}\text { Irregular then } \\
\text { persistent estrus }\end{array}$ & & & Kato et al. (2003) \\
\hline PND 1-21 & $2 \mathrm{mg}$ & Advanced & & & & $y$ & Marty et al. (1999) \\
\hline PND 5-VO & $0.5 \mu \mathrm{g}$ & Advanced & Advanced & & LHЛ & $\pi$ & Ramirez and Sawyer (1965) \\
\hline PND 10 & $10 \mathrm{mg}$ & Advanced & Advanced & $\begin{array}{l}\text { Irregular then } \\
\text { persistent estrus }\end{array}$ & $\begin{array}{l}\text { GnRH pulse } \\
\text { frequency } \pi\end{array}$ & & Matagne et al. (2004) \\
\hline PND 12-VO & & Advanced & & & $\begin{array}{l}\mathrm{FSH} / \mathrm{LH} \text { response } \\
\text { to GnRHy }\end{array}$ & & Nass et al. (1984) \\
\hline PND 21-23 & $10 \mu \mathrm{g}$ & Advanced & & & & $\pi$ & $\begin{array}{l}\text { Ashby et al. (1997a,b), } \\
\text { Odum et al. (1997) }\end{array}$ \\
\hline PND 23-26 & $5 \mu \mathrm{g}$ & Advanced & & & & $\pi$ & Korach et al. (1978) \\
\hline PND 25-42 & $0.3 \mu \mathrm{g}$ & Advanced & Advanced & & & & Edgren et al. (1966) \\
\hline PND 26-VO & $0.5 \mu \mathrm{g}$ & Advanced & & & & ス & Ramirez and Sawyer (1965) \\
\hline
\end{tabular}

PND: postnatal day; VO: vaginal opening; HP: hypothalamic-pituitary.

E2 has been usually administered postnatally starting either at birth or by PND 5-12, i.e. at the end of the critical period of sex differentiation or during the third week of life (Table 1). In all instances, VO was advanced as a possible result of either direct peripheral effects or early HPG maturation or both. The age at first estrus was usually not mentioned except in two studies. In the pioneering study of Ramirez and Sawyer (1965), injections of E2-benzoate (E2B, $0.5 \mu \mathrm{g} / \mathrm{kg}$ day) starting from PND 5 or 26 until VO in rats caused an advancement in age at both VO and first estrus. When administered after PND 20, E2 also advanced the age at VO (Edgren et al., 1966; Ashby et al., 1997a,b; Odum et al., 1997). Early VO and first estrus were also observed in our laboratory after a single massive dose of E2 (10 mg/kg day) given on PND 10 (Matagne et al., 2004). Cycling disturbances were found after treatment during the first 10 postnatal days (Kato et al., 2003) as a possible result of disturbed sex differentiation of central nervous system. However, cycling disorders were seen as well after treatment between PND 12 and VO, suggesting another additional mechanism. Evidence of pituitary inhibition has been obtained after E2 treatment starting on PND 12 since gonadotrophin response to GnRH was diminished by 5 months of age (Nass et al., 1984). Studies using immortalized GnRH-secreting cell line GT1-7 revealed that E2 downregulated GnRH transcript levels, indicating also a hypothalamic inhibition (Roy et al., 1999). However, E2 was found to stimulate GnRH secretion by these GT1-7 cells, an effect mediated by transforming growth factor (TGF) $\beta 1$ derived from astrocytes (Zwain et al., 2002). Recently, a stimulation of GnRH pulse frequency was observed using hypothalamic expiants of immature female rats either incubated with E2 in vitro or after E2 administration in vivo (Matagne et al., 2004). Scarce data on pituitary function were obtained. After E2 treatment between PND 5 till VO, increased plasma LH was seen on PND 30 (Ramirez and Sawyer, 1965). Obviously, the interpretation of those data is difficult due to differences in age at treatment, dose and age at study. Korach et al. (1978) showed that uterus weight was doubled after injection of $5 \mu \mathrm{g} / \mathrm{kg}$ day of E2 between PND 23 and 26. 
Other studies reported also an uterine weight increase after later treatment (Ramirez and Sawyer, 1965; Gould et al., 1998). In a single study of rats fed early (from birth to weaning) with E2 (2-4 mg/kg day), decreased uterine weights were observed (Marty et al., 1999). However, as discussed below, early treatment with other estrogenic compounds resulted in uterine weight increase. These data point to a prominent and presumably direct stimulatory peripheral effect in the case of late treatment and, possibly, after early treatment as well.

Structural changes can also occur in the ovaries and peripheral estrogen sensitive organs. After $10 \mu \mathrm{g} / \mathrm{kg}$ day of E2 was administered between PND 1 and 10, polycystic ovaries were observed on PND 80 (Kato et al., 2003). In 2001, Ikeda et al. showed that a neonatal exposure to E2B (1 mg/kg day, PND 1-5) caused disorders in ovarian development and differentiation before PND 21. Several studies in mice exposed during the same period reported that E2 affected the mammary gland development and structure in the immature and adult animals (Mori et al., 1976; Warner, 1976; Tomooka and Bern, 1982; Bern et al., 1983; DiPaolo and Jones, 2000). An in utero exposure of late fetal rats (GD 16-20) to E2B (50 $\mu \mathrm{g} / \mathrm{kg}$ day) caused a smaller AGD in the offspring at birth (Levy et al., 1995).

\subsection{Two synthetic estrogens: diethylstilbestrol (DES) and ethynylestradiol (EE2)}

The clinical concept of EDCs has arised from the long-term adverse effects of DES. This synthetic nonsteroidal estrogenic chemical has been administered in high doses to pregnant women as an antiabortive medication to prevent miscarriage and other pregnancy complications between 1938 and 1971 in the United States (U.S.). By that year, the U.S. Food and Drug Administration issued a warning about its use after having found a relationship between an in utero exposure to this synthetic estrogen and the development of clear cell adenocarcinoma of the vagina and cervix in young women whose mothers had taken this substance while they were pregnant (Herbst and Anderson, 1990). Although DES has not been given for more than about 30 years, its effects continue to be seen. Indeed, women who were exposed to it through their mother display structural reproductive tractus anomalies and an increased infertility rate (Merino, 1991; Schrager and Potter, 2004). DES has been considered as a paradigmatic compound for estrogenic EDCs and is often used as reference to study the effects of other putative estrogenic substances. It does not bind $\alpha$-fetoprotein, an estrogen-binding plasma protein, and can thus bind ERs in the fetal tissues much more actively than endogenous estrogens (McLachlan and Newbold, 1987).

Table 2 Data on effects of diethylstilbestrol on several hypothalamic-pituitary-ovarian outcomes

\begin{tabular}{|c|c|c|c|c|c|c|}
\hline Age at treatment & $\begin{array}{l}\text { Dose } \\
(\mu \mathrm{g} / \mathrm{kg} \text { day })\end{array}$ & $\mathrm{VO}$ & Cyclicity & HP axis & $\begin{array}{l}\text { Uterus } \\
\text { weight }\end{array}$ & Ref. \\
\hline GD 1-21 & 5 & & Irregular & & & Levy et al. (1995) \\
\hline GD 1-PND 21 & 6.5 & Advanced & Irregular & FSH/LHУ & $\pi$ & Kubo et al. (2003) \\
\hline \multirow[t]{3}{*}{ GD 9-16 } & 0.01 & & & & ス & Newbold et al. (1983) \\
\hline & 2.5 & & & & $\pi$ & Newbold et al. (1998) \\
\hline & 100 & & & & $\pi$ & $\begin{array}{l}\text { Haney et al. (1984), Newbold et al. } \\
\text { (1983) }\end{array}$ \\
\hline GD 11-PND 20 & 15 & & Irregular & & & $\begin{array}{l}\text { Kwon et al. (2000), Mori et al. } \\
\text { (1976) }\end{array}$ \\
\hline PND 1-5 & 0.002 & & Irregular & & オthen & $\begin{array}{l}\text { Huseby and Thurlow (1982), } \\
\text { McLachlan et al. (1982), Tomooka } \\
\text { and Bern (1982), Newbold et al. } \\
\text { (1998), Branham et al. (1988) }\end{array}$ \\
\hline PND 12-VO & & Advanced & & & $\pi$ & Nass et al. (1984) \\
\hline PND 21-23 & & & Irregular & & & \\
\hline PND 20-22 & 0.2 & & $\begin{array}{l}\text { Irregular then } \\
\text { persistent estrus or } \\
\text { diestrus }\end{array}$ & & $\pi$ & $\begin{array}{l}\text { Sharpe et al. (1995), Ashby et al. } \\
(1997 \text { a,b), Cagen et al. (1999), } \\
\text { Nagao et al. (2000), Atanassova et } \\
\text { al. (2000) }\end{array}$ \\
\hline PND 21-40 & 5 & Advanced & $\begin{array}{l}\text { Irregular then } \\
\text { persistent estrus }\end{array}$ & & & Kim et al. (2002) \\
\hline PND 23-26 & 7 & & $\begin{array}{l}\text { Irregular then } \\
\text { persistent estrus }\end{array}$ & & & Korach et al. (1978) \\
\hline
\end{tabular}


As expected from the clinical observations made using DES, experimental administration of this compound often started in prenatal life though postnatal treatment was considered as well (Table 2). Irrespective of the period of treatment, VO was found to be advanced by DES when studied (Nass et al., 1984; Kim et al., 2002; Kubo et al., 2003). Disturbances in estrous cyclicity were commonly observed when DES was administered during either gestational or postnatal period or both. The animals displayed irregular cycles followed by persistent estrus or diestrus, causing reduced fertility $(0.01 \mu \mathrm{g} / \mathrm{kg}$ day) or complete sterility $(100 \mu \mathrm{g} / \mathrm{kg}$ day $)$, depending on DES dose. Exposure during fetal life and suckling period ( $6.5 \mu \mathrm{g} / \mathrm{kg}$ day) caused a decrease in FSH and LH secretion at 3 months of age, indicating a negative feedback effect on the HP axis (Kubo et al., 2003). The uterotrophic response to DES was evidenced in many studies, uterine weight being doubled even after a short period of postnatal exposure (PND 20-22 or 23-26, 0.2-7 $\mu \mathrm{g} / \mathrm{kg}$ day). Uterine abnormalities were also observed when 0.01$100 \mu \mathrm{g} / \mathrm{kg}$ day of DES were given prenatally (McLachlan et al., 1982; Newbold et al., 1983, 1984) and after a PND 1-5 exposure to $0.01 \mu \mathrm{g} / \mathrm{kg}$ day, resulting in permanent disorders of the reproductive ability (Branham et al., 1988; Hailing and Forsberg, 1993).

Some investigations focused on DES effects on the ovarian histoarchitecture. Anovulatory ovaries were observed (Döhler et al., 1984; Tarttelin and Gorski, 1988; Vancutsem and Roessler, 1997). Haney et al. (1984) reported that mice exposed in utero to $100 \mu \mathrm{g} / \mathrm{kg}$ day displayed an enlargement of the ovarian interstitial compartments at 3 months of age. Others showed that administration of DES in mice between PND 1 and 5 affected the growth ofmammary glands (Mori et al., 1976; Warner, 1976; Huseby and Thurlow, 1982; Tomooka and Bern, 1982; Bern et al., 1983; DiPaolo and Jones, 2000). When pregnant mice were fed with DES from GD 11 to GD 17, the AGD of the offspring at birth was decreased (Palanza et al., 2001).

EE2 is actually the most frequently used estrogenic component of the anovulatory contraceptive pills in women. This synthetic estrogenic compound is eliminated out of the body through the urines (Bolt et al., 1973; Bolt, 1979), thus contaminating the environment via the waste water. The experimental EE2 effects were mainly tested postnatally. In a study where age at VO was assessed, an advancement was observed after $100 \mu \mathrm{g} / \mathrm{kg}$ day, PND 21-35 (Laws et al., 2000). It was demonstrated (Odum et al., 1997) that an exposure through oral gavage was less effective than s.c. injection (2-400 $\mu \mathrm{g} / \mathrm{kg}$ day, PND 21-23). Laws et al. (2000) reported also that the number of regular cycles was reduced, pointing to peripheral and central effects. Investigations of the uterotrophic response showed an increase in uterus weight after 0.3-100 $\mu \mathrm{g} / \mathrm{kg}$ day, during PND 21-23 (Freyberger et al., 2001; Laws et al., 2000). Similar results were observed when EE2 was administered in early life, PND 1-5 (Branham et al., 1988).

\subsection{Phytoestrogens}

Plants produce estrogen-like substances, called phytoestrogens. They are nonsteroidal EDCs naturally carried from food. There is a growing body of literature showing that these estrogens are capable of binding to ERs and exerting estrogenic responses in mammals (Martin et al., 1978; Nelson et al., 1984; Hopert et al., 1998). They include mainly the isoflavones (e.g. genistein found in soy derivatives) and the coumestanes (principally coumestrol present in several vegetables). Trans-resveratrol (RVT), a stilbene derivative, is a phytoalexin found in grapes, red wine, peanuts and other fruits. Little information is known about its estrogenic potential (Gehm et al., 1997).

Table 3 Data on effects of phytoestrogens on several hypothalamic-pituitary-ovarian outcomes

\begin{tabular}{|c|c|c|c|c|c|c|}
\hline $\begin{array}{l}\text { Age at } \\
\text { treatment }\end{array}$ & $\begin{array}{l}\text { Dose } \\
\text { (mg/kg day) }\end{array}$ & EDCs & $\mathrm{VO}$ & Cyclicity & $\begin{array}{l}\text { Uterus } \\
\text { weight }\end{array}$ & Ref. \\
\hline GD 1-PND 21 & 1.5 & RVT & Delayed & Irregular & & Kubo et al. (2003) \\
\hline \multirow[t]{2}{*}{ GD 16-20 } & 5 & Genistein & Delayed & & & Levy et al. (1995) \\
\hline & 25 & Genistein & Delayed & & $\pi$ & Gallo et al. (1999) \\
\hline \multirow[t]{2}{*}{ PND 1-5 } & 0.1 & Coumestrol & & & オthen $У$ & Medlock et al. (1995) \\
\hline & 0.5 & Genistein & & Prolonged estrus irregular & & Jefferson et al. (2005) \\
\hline 3 days & 18 & RVT & & & $y$ & Freyberger et al. (2001) \\
\hline PND 21-23 & 20 & Coumestrol & Advanced & & ス & Baker et al. (1999) \\
\hline PND 21-27 & & Genistein & Advanced & Irregular & $\pi$ & Gallo et al. (1999) \\
\hline PND 22-60 & & Coumestrol & & Irregular & & $\begin{array}{l}\text { Whitten and Naftolin } \\
\text { (1992) }\end{array}$ \\
\hline
\end{tabular}


Phytoestrogens were studied in rodents during all the periods of life till adulthood (Table 3). Discrepant effects were obtained when VO was studied depending on species and time of exposure. Administration of genistein (5 $\mathrm{mg} / \mathrm{kg}$ day) during fetal life (GD 16-20) delayed the age at VO (Levy et al., 1995) while when given between PND 21 and 27, VO was advanced (Gallo et al., 1999). VO advancement was also obtained after coumestrol administration during PND 22-60 (Whitten and Naftolin, 1992). Early exposure to RVT (1500 $\mu \mathrm{g} / \mathrm{kg}$ day) during fetal and suckling periods caused a delay in age at VO (Kubo et al., 2003). Irregular cycles, i.e. increase or decrease in cycle duration, were reported in several studies (Whitten and Naftolin, 1992; Gallo et al., 1999; Freyberger et al., 2001; Jefferson et al., 2005). Coumestrol was also found to inhibit the GnRH transcript expression in GT1-7 cells (Bowe et al., 2003). McGarvey et al. (2001) showed that coumestrol profoundly inhibited the pulsatile LH secretion with concomitant reduction of the frequency of hypothalamic multiunit electrical activity volleys. In addition, the GnRH-induced pituitary LH release in vitro in rat was completely suppressed. Genistein, however, had no effects on pulsatile LH secretion. As observed for VO, contradictory results were also obtained concerning the effects on uterus. Uterine weight was increased by $25 \mathrm{mg} / \mathrm{kg} \mathrm{day} \mathrm{of}$ genistein given GD 16-20 (Levy et al., 1995; Gallo et al., 1999) and 20-80 mg/kg day of coumestrol given PND 21-23 (Baker et al., 1999) whereas Medlock et al. (1995) reported an initial increase and subsequent decrease in uterine weight after $100 \mu \mathrm{g} / \mathrm{kg}$ day of coumestrol given PND 1-5. A decrease in uterine weight was caused by RVT (18, 58 or $575 \mathrm{mg} / \mathrm{kg}$ day) given on 3 consecutive days (Freyberger et al., 2001). Gallo et al. (1999) described disturbances in the distribution of ovarian follicular size after genistein. Moreover, Jefferson and Newbold (2000) reported multi-oocyte follicles in the ovaries when mice were exposed to environmentally relevant dose (50 mg/kg day, s.c.) of genistein. Levy et al. (1995) demonstrated that pregnant rats injected with 5 $\mathrm{mg} / \mathrm{kg}$ day of genistein during GD 16-20 had their offspring with a smaller AGD at birth.

Studies of nutritional effects on the timing of human puberty have focused on questions around obesity, fat and protein contents of the food, and there is very little information on possible effects of phytoestrogens (Berkey et al., 2000).

\subsection{DDT and other insecticides}

Many organochlorine pesticides are extremely persistent and tend to bioaccumulate. The insecticide DDT can behave as an estrogen agonist and/or an androgen antagonist. It has been banned in the U.S. and Western European countries since the late 1960s but is still used extensively in developing countries where contamination continues via the consumption of foods (Key and Reeves, 1994; Kelce et al., 1995; Clark et al., 1998; Partsch and Sippel, 2001 ; Parent et al., 2003). Two DDT isomers exist, $p, p^{\prime}-$ and $o, p^{\prime}$-DDT, the first one representing approximately $80 \%$ of DDT spread in the environment. Methoxychlor (MXC) was developed to replace DDT and to have a similar spectrum of intended effects while being more readily excreted. It has a much reduced tendency to accumulate in the nature compared to DDT (Kapoor et al., 1970). It stimulates the estrogenic activity presumably through the ability of some of its metabolite hydroxyphenyltrichloroethane (HPTE) to bind to intracellular ERs (Bulger et al., 1978a,b). The effects of the broad spectrum insecticide lindane, still relatively widespread in developed nations as well as in the third world, will also be discussed in this review. It can affect the endocrine system through its isomer hexachlorocyclohexane that is long persistent in the environment and tends to bioaccumulate along food chains.

Data from Gray et al. $(1988,1989)$ reported that MXC $(25-200 \mathrm{mg} / \mathrm{kg}$ day) given from weaning onwards resulted in advancement in age at VO and first estrus. Laws et al. (2000) showed that a 3-day exposure (PND 21$23)$ to $\mathrm{MXC}(50 \mathrm{mg} / \mathrm{kg}$ day) also caused advancement in age at VO (Table 4). Lindane (5-40 $\mathrm{mg} / \mathrm{kg}$ day) given PND 21-110 or 125 was found to delay the age at VO (Cooper et al., 1989). This observation suggests that, during prolonged exposure to a compound with evidence of few or no peripheral estrogenic effects, the central inhibitory effects can be prominent. Consistent with this interpretation, Cooper et al. (1989) observed that 20-40 $\mathrm{mg} / \mathrm{kg}$ day of lindane caused a reduced size of pituitary gland associated with high FSH and low LH concentrations, along with a decrease in uterine weight (Table 4) and a disruption of the ovarian cyclicity. Further about a putative central effect of pesticides, Gray et al. $(1988,1989)$ observed that, following administration of $200 \mathrm{mg} / \mathrm{kg}$ day of MXC, the length of estrous cycles was increased until a persistent estrus was seen. A decrease in the number of regular (4-5 days) estrous cycles was also noted (Laws et al., 2000). Treatment with $10 \mathrm{mg} / \mathrm{kg}$ day of lindane (Cooper et al., 1989) was followed by periods of persistent estrus or diestrus (Table 4). Using the GnRH-secreting GT1-7 cell line, MXC was found to down-regulate the GnRH transcript levels through its metabolite HPTE (Roy et al., 1999; Gore, 2002). MXC given orally or s.c. (50 or $500 \mathrm{mg} / \mathrm{kg}$ day, PND 21-23) accounted for an increase in uterine weight (Odum et al., 1997; Laws et al., 2000). When pregnant mice (GD 11-17) were fed with $o, p^{\prime}$-DDT or MXC, a decrease of the AGD was observed in the offspring at birth (Palanza et al., 2001). 
Published in: Molecular \& Cellular Endocrinology (2006), vol. 254-255, pp. 187-201.

Status: Postprint (Author's version)

Table 4 Data on effects of pesticides on several hypothalamic-pituitary-ovarian outcomes

\begin{tabular}{|c|c|c|c|c|c|c|c|}
\hline $\begin{array}{l}\text { Age at } \\
\text { treatment }\end{array}$ & $\begin{array}{l}\text { Dose } \\
\text { (mg/kg day) }\end{array}$ & EDCs & $\mathrm{VO}$ & Cyclicity & HP axis & $\begin{array}{l}\text { Uterus } \\
\text { weight }\end{array}$ & Ref. \\
\hline PND 21-23 & 50 & $\mathrm{MXC}$ & & & & $\pi$ & $\begin{array}{l}\text { Laws et al. } \\
(2000)\end{array}$ \\
\hline PND 21-35 & & & Advanced & & & & $\begin{array}{l}\text { Cooper et al. } \\
(1989)\end{array}$ \\
\hline 25 days & 5 & Lindane & & Irregular & & & \\
\hline PND 21-110 & 10 & Lindane & Delayed & $\begin{array}{l}\text { Irregular then } \\
\text { persistent estrus } \\
\text { or diestrus }\end{array}$ & & & \\
\hline & 20 & Lindane & & & Pituitary weight $\ F S H \lambda / L H У$ & $y$ & \\
\hline
\end{tabular}

PND: postnatal day; EDCs: endocrine disrupting chemicals; MXC: methoxychlor; VO: vaginal opening; HP: hypothalamic-pituitary.

Since the persistent DDT derivative $p, p^{\prime}$-DDE was found in the serum of foreign migrating children developing sexual precocity in Belgium (Krstevska-Konstantinova et al., 2001; Parent et al., 2003), we have been interested in delineating the possible effects of DDT on the HP axis. Preliminary observations (Rasier et al., 2005) indicate that $o, p^{\prime}$-DDT could have stimulatory effects on GnRH secretion similar to those of E2 with involvement of ERs and the kainate subtype of glutamate receptor as well as the orphan dioxin receptor following a mechanism described by Ohtake et al. (2003). Additional mechanisms could exist since DDT was reported recently to stimulate brain aromatase (Kuhl et al., 2005). We obtained preliminary data showing that exposure of immature female rats for 5 days to $o, p^{\prime}$-DDT as well as E2 in 1000:1 concentration ratio could result in early developmental acceleration of GnRH secretion and subsequent sexual precocity (Rasier et al., 2005). This is consistent with the above-mentioned model of central precocity occurring as a consequence of exposure to and withdrawal from an EDC.

High levels of $p, p^{\prime}$-DDE was found in 26 immigrant girls with precocious puberty as compared to 15 Belgian patients with the same diagnosis (Krstevska-Konstantinova et al., 2001). Only two Belgian girls had detectable serum DDE concentration, whereas the mean concentration in immigrant girls was 10 times higher than the detection limit. Three of the immigrant children with high DDE levels had been born in Belgium, suggesting trans-placental and lactational exposure, because the half-life of DDE is very long. The DDE levels correlated positively with the age of immigration and negatively with the time since immigration, suggesting that the source of contamination was in the home country (Parent et al., 2003).

In the Michigan anglers cohort, exposure to DDT of fish-eating mothers and their controls was measured, and the timing of puberty in 151 daughters was studied (Vasiliu et al., 2004). In utero exposure to high levels of DDE was associated with an advanced age at menarche. In the North Carolina Infant Feeding study of 316 girls and 278 boys, no significant exposure-outcome associations between DDE and pubertal timing were found (Gladen et al., 2000).

Pubertal delay was associated to a high endosulfan exposure in a recent Indian study where 117 boys from a highly contaminated area were compared to 90 matched control boys from uncontaminated area (Saiyed et al., 2003). Antisteroidogenic properties of endosulfan could contribute to this effect.

\subsection{Bisphenol A (BPA) and phenol derivatives}

BPA is a most common EDC in our environment. It is used in the manufacture of polycarbonate plastics and epoxy resins, from which a variety of products are made, including reusable milk and food storage containers, baby formula bottles, interior lacquer-coating of food cans or dental sealants, indicating that humans are exposed widely to this chemical (Krishnan et al., 1993). Indeed, BPA has been detected in the human umbilical cord blood, pointing to a possible fetal contamination (Sakurai and Mori, 2000; Brock et al., 2001). This compound has been found to compete with E2 for binding to ERs (Krishnan et al., 1993; Hiroi et al., 1999). However, its affinity for those receptors has been shown to be much weaker than that of E2 (Kwon et al., 2000).

As shown in Table 5, when administered (s.c.) postnatally starting either from birth or later in life, BPA (600$800 \mathrm{mg} / \mathrm{kg}$ day, PND 21-23; 1 or $4 \mathrm{mg} / \mathrm{kg}$ day, PND 1-10) was found to advance the age at VO (Ashby and Tinwell, 1998; Kato et al., 2003). It was also shown that a fetal exposure (GD 11-17) to a low dose $(2.4 \mu \mathrm{g} / \mathrm{kg}$ day) reduced the time interval between VO and first estrus (Howdeshell et al., 1999). Early and prolonged administration (GD 6-PND 21; $1.2 \mathrm{mg} / \mathrm{kg}$ day) also accounted for disruption in estrous cyclicity (Rubin et al., $2001)$ while a single administration $(100 \mathrm{mg} / \mathrm{kg}$ day, 25 days, orally) resulted in a decrease of the number of regular cycles (Laws et al., 2000) with subsequent persistent estrus (Ashby and Tinwell, 1998; Kato et al., 2003). Rubin et al. (2001) showed that serum LH levels decreased in adulthood, suggesting the involvement of a 
negative feedback effect. Concerning the reproductive tract, an uterotrophic response was observed after a 3-day exposure (PND 21-23) to 37.5-150 mg/kg day (Ashby and Tinwell, 1998; Steinmetz et al., 1998), $200 \mathrm{mg} / \mathrm{kg}$ day, orally (Laws et al., 2000) or 200-800 mg/kg day (Ashby and Odum, 2004). Taken together, those data indicate stimulatory peripheral effects and inhibition of the central mechanism of ovulatory cycles. Kato et al. (2003) observed polycystic ovaries in adulthood. Markey et al. (2001) showed that when mice were exposed in utero (GD 9-20) to low, presumably environmentally relevant doses of BPA ( 25 or $250 \mu \mathrm{g} / \mathrm{kg}$ day, s.c), changes in histoarchitecture of mammary glands occurred. Very recently, Munoz-de-Toro et al. (2005) reported same disorders in adult mice when 25 or $250 \mathrm{ng} / \mathrm{kg}$ day of BPA were administered from GD 9 till PND 4.

Table 5 Data on effects of bisphenol A on several hypothalamic-pituitary-ovarian outcomes

\begin{tabular}{|c|c|c|c|c|c|c|}
\hline $\begin{array}{l}\text { Age at } \\
\text { treatment }\end{array}$ & $\begin{array}{l}\text { Dose } \\
\text { (per kg day) }\end{array}$ & VO & Cyclicity & HP axis & $\begin{array}{l}\text { Uterus } \\
\text { weight }\end{array}$ & Ref. \\
\hline GD 6-PND 21 & $1.2 \mathrm{mg}$ & & Irregular & LHУ & & Rubin et al. (2001) \\
\hline GD 11-17 & $2.4 \mu \mathrm{g}$ & $\begin{array}{l}\text { Number of days } \\
\text { between VO and } \\
\text { 1st estrus } y\end{array}$ & & & & Howdeshell et al. (1999) \\
\hline \multirow[t]{2}{*}{ PND 1-10 } & $1 \mathrm{mg}$ & Advanced & & & & Kato et al. (2003) \\
\hline & $4 \mathrm{mg}$ & & $\begin{array}{l}\text { Irregular then persistent } \\
\text { estrus }\end{array}$ & & & \\
\hline \multirow[t]{3}{*}{ PND 21-23 } & $37.5 \mathrm{mg}$ & & & & $\pi$ & Steinmetz et al. (1998) \\
\hline & $200 \mathrm{mg}$ & & & & $\pi$ & $\begin{array}{l}\text { Laws et al. (2000), Ashby and } \\
\text { Odum (2004) }\end{array}$ \\
\hline & $600 \mathrm{mg}$ & Advanced & $\begin{array}{l}\text { Irregular then persistent } \\
\text { estrus }\end{array}$ & & & Ashby and Tinwell (1998) \\
\hline PND 23-25 & $100 \mathrm{mg}$ & & & & $\pi$ & Markey et al. (2001) \\
\hline 25 days & & & Irregular & & $\pi$ & $\begin{array}{l}\text { Laws et al. (2000), Markey et } \\
\text { al. (2001) }\end{array}$ \\
\hline
\end{tabular}

GD: gestational day; PND: postnatal day; VO: vaginal opening; HP: hypothalamic-pituitary.

A number of alkylphenol compounds in the environment have been also reported to affect estrogenic activity in the endocrine system. Octylphenol, notably used in the manufacture of plastics, has been detected in food and water consumed by animals and people. When 100-200 mg/kg day were given orally from PND 21 until VO, an advancement in the age at VO was observed (Gray and Ostby, 1998). A $10 \mathrm{mg} / \mathrm{kg}$ day (s.c.) was found to increase uterine weight in prepubertal rats (Bicknell et al., 1995). Similar results were reported by Laws et al. (2000) with $200 \mathrm{mg} / \mathrm{kg}$ day (PND 21-35, orally), along with disruption in estrous cyclicity after 20-40 mg/kg day s.c. (Blake and Ashiru, 1997) and disorders in pituitary hormone levels after $80 \mathrm{mg} / \mathrm{kg}$ day s.c. (Blake and Bookfor, 1997). Nonylphenol, which is widely used in the production of many surfactants and plastics, has been reported to advance the age at VO after 50-100 mg/kg day, PND 21-35 (Laws et al., 2000). When given between PND 21 and 40 at the same doses, advancement in age at VO and irregular estrous cycles following an increase length of diestrus were also seen (Kim et al., 2002). An uterotrophic response was observed (Odum et al., 1997; Laws et al., 2000) after treatment with 100-200 mg/kg day s.c. during PND 20-22 (Kim et al., 2002). Thus, alkylphenols accounted to effects very comparable to those of BPA.

To our knowledge there are no human studies on the association of alkylphenol or BPA exposure to timing of puberty. Assessment of exposure is difficult as compared to persistent compounds such as PCBs and DDE that can be measured years after the exposure.

\subsection{Poly chlorinated biphenyls (PCBs)}

There is paucity of information describing the effects of exposure to PCBs. They are lipophilic industrial chemicals often detected in human breast milk, serum or tissues. They can have estrogenic and antiandrogenic activities. The effects of two PCB mixtures, Aroclor 1221 (A1221) and A1254, were tested on the hypothalamic neuronal GT1-7 cells by Gore et al. (2002). A1221 increased GnRH transcript and peptide levels. A1254 had different effects, inhibiting GnRH transcription at high concentrations and elevating transcript levels at low concentrations. Moreover, it did not alter GnRH peptide levels. When pregnant female rats were exposed (GD 121) via food containing $40 \mathrm{mg} / \mathrm{kg}$ day of a reconstituted PCB mixture (composed according to the congenerpattern in human breast milk), Hany et al. (1999) showed that the breastfed pups exhibited elevated uterine weights on PND 21. 
There are already several epidemiological studies that have assessed exposure to PCBs in relation to the timing of puberty. In a Belgian study comparing children (120 girls and 80 boys) from rural and urban areas, PCB congeners 138,153 and 180 were measured in serum, and the pubertal stage was assessed by trained physicians (Staessen et al., 2001 ; Den Hond et al., 2002). No association of PCB levels to pubertal development in girls was observed, whereas in boys, a significant delay of puberty was found in urban areas and in association with high PCB levels. In the North Carolina Infant Feeding Study, no association of PCB exposure to the selfreported timing of puberty (including age at menarche) among 316 girls and 278 boys were found, although there was a nonsignificant tendency to early maturation in the girls in the highest prenatal exposure group (Gladen et al., 2000). Two studies from the Great Lake area, Michigan in U.S., found no correlation of PCB exposure to self-reported timing of puberty in 327 (Blanck et al., 2000) or 151 girls (Vasiliu et al., 2004). Similar results were found in a boy cohort (196 boys) from Faroe Islands, i.e. no association of PCB exposure to the timing of puberty (Mol et al., 2002). In Yucheng, 55 boys who were accidentally exposed to high PCB and polychlorinated dibenzofuran (PCDF) levels were reported to have shorter penile length than the control boys at the same age, suggesting pubertal delay (Guo et al., 2004). In summary, epidemiological studies have not revealed any association of $\mathrm{PCB}$ exposure with the timing of puberty in girls, whereas in boys, there are two studies suggesting a link to delayed puberty and two studies showing no effect.

\subsection{Polybrominated biphenyl (PBB)}

Animal feed was contaminated with polybrominated biphenyl in a farm in Michigan in the 1970s causing a high exposure of thousands of people via milk and other products from contaminated cows. Perinatal exposure of children was estimated by measuring PBB in serum of mothers some years after exposure. The girls that had been exposed to high PBB levels through lactation had an earlier age at menarche and earlier pubic hair development than those who were less exposed through breastfeeding, whereas no differences were found in breast development. The girls reported their pubertal development themselves, and this may have caused more inaccuracy and variation in timing of breast development than other pubertal landmarks (Blanck et al., 2000).

\subsection{Phthalates}

Phthalates are plasticizers and thus can contaminate environment and humans by consumption of food or drinks contained in plastic package or bottles. Ashby et al. (1997a,b) reported that when $182.6 \mu \mathrm{g} / \mathrm{kg}$ day of butyl benzyl phthalate (BBP) was administered orally to rats from conception until weaning, VO was advanced in the offspring. Similarly, pups whose mother was exposed from the first day of gestation until birth to dibutyl phthalate DBP (12 or $50 \mathrm{mg} / \mathrm{kg}$ day, orally) had age at VO and first estrus advanced (Salazar et al., 2004). Nagao et al. (2000) conducted a study in pregnant female rats using a $500 \mathrm{mg} / \mathrm{kg}$ day oral dose of BBP. The AGD was increased in the offspring at birth.

Puerto Rican epidemy of thelarche has prompted studies on several putative endocrine disrupters, including phthalates (Colon et al., 2000). In the case-control study of 41 girls with thelarche and 35 controls, two-thirds of the cases had measurable phthalate levels in serum, whereas only $14 \%$ of the controls had detectable phthalates. However, the phthalate profile in serum raised a concern about possible technical errors (or contamination), because diethyl hexyl phthalate concentrations were high as compared to other phthalates (McKee, 2004).

\subsection{Dioxins}

Immature female rats were given single oral doses $(0.3-60 \mu \mathrm{g} / \mathrm{kg})$ of the environmental toxicant $2,3,7,8$ tetrachlorodibenzo-p-dioxin (TCDD) on PND 22 and equine chorionic gonadotrophin (eCG) $24 \mathrm{~h}$ later to induce follicular development. A dose-dependently increase in ovarian weight and a decrease in number of animals ovulating were observed. Peak serum levels of FSH and LH were decreased by TCDD. In hypophysectomized immature rats treated with eCG and exogenous LH, number of rats ovulating was reduced by TCDD (10 and 60 $\mu \mathrm{g} / \mathrm{kg}$ ), suggesting that TCDD alters reproductive functions via effects on the HP axis as well as through direct effects on the ovary ( $\mathrm{Li}$ et al., 1995). Single doses $(0.03-30 \mu \mathrm{g} / \mathrm{kg})$ of TCDD were also administered orally by gastric intubation to 22-day-old rats. Peaks of FSH and LH were observed immediately after treatment and 1 day later. This dose-dependent elevation indicated that TCDD induces release of gonadotrophins. Such a stimulation was at least partially due to a direct pituitary effect since TCDD caused a release of LH in vitro from pituitary halves and primary pituitary cell cultures (Li et al., 1997). Recently, it was also demonstrated that 8 or $32 \mu \mathrm{g} / \mathrm{kg}$ of TCDD administered to immature female rats induced a premature increase in FSH and LH in vivo, this effect being facilitated by administration of a long-acting E2 (Petroff et al., 2003).

Retrospective analyses of the age at menarche in girls exposed to TCDD in Seveso 1976 found no association (Warner et al., 2004). However, it remained open whether the timing of exposure was appropriate in terms of pubertal effects. In the Yucheng rice oil accident, children were exposed to PCDF that were formed through heat-degradation of PCB contaminants in food preparation (Guo et al., 2004). As described earlier, the exposed boys had smaller penises as compared to control subjects at the same age. In the Belgian study of children from 
rural and two urban areas, dioxin exposure was estimated with the Calux assay that measures the total dioxinlike activity in serum (Staessen et al., 2001; Den Hond et al., 2002). Higher dioxin-like activities were measured in children from the urban suburbs than in those from the rural area. There was no correlation of the activity with the age at menarche or pubic hair development, but breast development to the adult stage was inversely correlated to dioxin-like activity, i.e. high exposure was associated with a developmental delay (Den Hond et al., 2002). In boys, there was no correlation of dioxin-like activity with landmarks of pubertal development, although testes of boys in the polluted urban areas were significantly smaller than those in the rural area (Den Hond et al., 2002). Dioxins act through the aryl hydrocarbon receptor (AhR) and have antiestrogenic effects in vitro (Wormke et al., 2003) which might contribute to the slow breast development in highly exposed girls. Estrogenic effects, however, have been reported as well through interaction of the dioxin-AhR-nuclear translocator complex with ERs (Ohtake et al., 2003).

\subsection{Lead}

High lead levels in blood were reported to be associated to a delayed age at menarche and delayed pubic hair development in two studies that were based on the National Health and Nutrition Examination Survey in U.S. (NHANES III) (Selevan et al., 2003; Wu et al., 2003). Breast development was also found to be delayed in the study including 2186 girls (Selevan et al., 2003).

\subsection{Geographic trends}

High incidence of central precocious puberty was recently reported in a small region in Northwest Tuscany, Viareggio, but the cause for the difference to the neighbouring areas remains open (Massart et al., 2005). However, the regional differences may give clues to further exploration of potential causal agents. Viareggio area has many small navy yards and greenhouses that may be sources of pollutants contributing to the effect.

\section{Concluding remarks}

During past decades, the birth rate has declined in a number of industrialized countries (Davis et al., 1998). The reason of this reduction is not really clear, but it has been suggested that chronic exposures to toxic environmental agents, that predominantly affect the reproductive system, could lead to this lower rate (Potashnik et al., 1984; Rogan et al., 1999; Mocarelli et al., 2000; Hama et al., 2001; Sakamoto et al., 2001). The time interval between exposure to such substances can be very long and early prenatal and postnatal life is probably a critical window for exposure. For instance, a 32\% fall in probability of pregnancy was found in daughters of mothers with $10 \mu \mathrm{g} / \mathrm{l}$ of $p, p^{\prime}$-DDT in blood drawn at the time of delivery, 30 years earlier (Cohn et al., 2003).

Indeed, we are continuously exposed to a number of natural and artificial chemical substances which bioaccumulate in the environment. These substances, mostly showing estrogenic activity, potentially interfere with the endocrine system, altering the hormone actions through the ER ( $\alpha$ and/or $\beta$ ) pathway (synthesis and/or receptor binding). While EDC effects on female reproduction have been a matter of concern for several decades, female pubertal development has emerged more recently as a possible endpoint. Current knowledge of exposureoutcome relationships in pubertal timing is limited to few epidemiological studies. In many of those studies, timing of pubertal stages and menarche were self-reported and the assessment of exposure indirect, both of which cause considerable variation to data. The size of the study populations varies also largely. High levels of DDE in serum of immigrant girls with central precocious puberty was found (Krstevska-Konstantinova et al., 2001) and a high perinatal exposure to DDE levels was also associated to early menarche in the so-called Michigan angler cohort (Vasiliu et al., 2004), whereas in the North Carolina Infant Feeding Study, no association was found between DDE exposure and pubertal timing (Gladen et al., 2000). A high perinatal exposure to PBB was associated to early menarche and pubic hair development, but not to timing of breast development (Blanck et al., 2000). Dioxins and PCBs do not seem to affect pubertal development in girls, but one study reported an association of PCBs to a delay in pubertal development in boys (Den Hond et al., 2002). Endosulfan exposure was also associated with slower pubertal development in boys (Saiyed et al., 2003) and lead exposure with delayed pubertal timing in girls (Selevan et al., 2003; Wu et al., 2003).

The animal data tend to substantiate effects of early exposure to EDCs on HPG axis with alterations of sexual maturation and reproductive functions in female rodents. It has always been controversial to extrapolate from data that are obtained in laboratory animals in which the dose and time of chemical exposure do not always represent conditions that humans face in their habitat during a life time. However, we cannot ignore the increasing evidence coming from these studies when human populations are exposed to the same chemicals during developmental stages.

When all instances of EDC exposure are taken together, both peripheral and central effects were observed. In most cases, advancement in the age at VO was reported though some EDCs such as genistein, RVT and lindane accounted for some delay. The advancement in age at VO suggests a peripheral effect occurring directly on vaginal epithelium, the acceleration being a sign of a premature estrogenic activity and the delay, an 
antiestrogenic effect. Uterine weight increase, which is known to be a marker of estrogenicity, was also commonly observed when studied after exposure to estrogenic EDCs. Since genistein as well as RVT can act as mixed agonists/antagonists at the ERs (Miodini et al., 1999; Bowers et al., 2000), a prominent antagonistic pathway is suggested by the delay. Little is known about the mechanism of action of HPTE, the active isomer of lindane, Cooper et al. (1989) suggesting an antiestrogenic effect.

After an exposure to E2, the age at first estrus was advanced as noted for VO. This effect suggests a central stimulatory involvement, resulting from acceleration in hypothalamic maturation. Such an hypothesis was supported by the increase in GnRH pulse frequency seen after in vivo and in vitro E2 administration (Matagne et al., 2004). Irregular cyclicity followed by persistent estrus or diestrus, associated with subfertility or complete sterility was shown in most studies with all types of EDCs, indicating an additional disturbing impact on the hypothalamic functions. The interpretation of such findings is complex since it can involve disorders of the perinatally programmed central mechanism of ovulation that is highly sensitive to interactions at ERs and inhibitory effects disordering hypothalamic function later in life. The latter component is consistent with the direct action of coumestrol centrally to reduce the frequency of the hypothalamic GnRH pulse generator (McGarvey et al., 2001). In addition, Bowe et al. (2003) showed that ER $\beta$ was involved in the suppression of GnRH transcript expression by coumestrol in GnRH-secreting neuronal GT1-7 cells. Direct central stimulatory effects are consistent with some findings using the GT1-7 cell line, where E2 and A1221 directly stimulated GnRH gene expression, through interaction with specific receptors expressed in these cells. As effects of A1221 on GnRH gene expression were not blocked by ICI 182,780, it indicated that some but not all of its effects were mediated by the classical ER ( $\alpha$ and/or $\beta$ ) pathway (Gore et al., 2002). TCDD appeared to stimulate premature gonadotrophin release in the gonadotrophin-primed immature rat by interacting with an E2-sensitive neural signal (Petroff et al., 2003). Nass et al. (1984) concluded that exposure to exogenous estrogen prior to puberty precipitates the decline in estrous cyclicity associated with the loss of gonadotrophin surge response presumably due to an alteration in hypothalamic GnRH release. Again evidence of both stimulatory and inhibitory central effects is provided by these observations.

Besides hypothalamic effects, EDC could have direct action at the pituitary gland level. It was shown that coumestrol inhibited pituitary LH pulses by reducing responsiveness to GnRH via an ER-mediated process (McGarvey et al., 2001).

When EDC effects are considered, the exposure issue including age, dose and mixture effects is critical. The observations reviewed here deal with in vivo data which can be different from in vitro models commonly used to compare biopotency of EDCs. Except for DES which is known to be as or even more potent than E2, the doserelated potency ratio between E2 and other EDCs usually ranges between 1:1000 and 1:10,000. However, because differences in doses are usually associated with differences in age at treatment, duration and route of administration, comparisons are difficult. In utero and/or early postnatal administration causes generally more severe disturbances involving central effects whereas late postnatal exposure mainly cause an uterotrophic response and other peripheral disorders. Most authors reported that s.c. injections were more effective or required a lower dose to induce an effect than an oral gavage. Differences in absorption, metabolic activation and/or elimination of tested chemicals can occur following the exposure subcutaneously or orally (Klaassen and Eaton, 1991).

A thorough assessment of effects of exposure to EDCs before, around and/or after birth is indispensable for a real understanding of the exposure-disorder relationships in the immature female animals and, by extension, in the young girls. We have also to remind that it is not the individual exposure to a single xenoestrogen but rather the cumulative exposure to multiple xenoestrogens that determines the intensity of the effects (Soto et al., 1994, 1997). Finally, disorders of female sexual development can be a relatively early manifestation of EDC effects that should be put in perspective as warning towards more severe and later consequences such as fertility disorders and neoplasia of estrogen-sensitive tissues.

\section{Acknowledgements}

This work has been supported by grants from the "Fonds de la Recherche Scientifique Médicale" (grant 3.4515.01), the Belgian Study Group for Paediatric Endocrinology and the European Commission (contract no. QLRT-2001-00269).

\section{References}

Ashby, J., Odum, J., Foster, J.R., 1997a. Activity of raloxifene in immature and ovariectomized rat uterotrophic assays. Regul. Toxicol. Pharmacol. 25, 226-231.

Ashby, J., Tinwell, H., Lefevre, P.A., Odum, J., Paton, D., Millward, S.W., Tittensor, S., Brooks, A.N., 1997b. Normal sexual development of rats exposed to butyl benzyl phthalate from conception to weaning. Regul. Toxicol. Pharmacol. 26, $102-118$. 
Published in: Molecular \& Cellular Endocrinology (2006), vol. 254-255, pp. 187-201.

Status: Postprint (Author's version)

Ashby, J., Tinwell, H., 1998. Uterotrophic activity of bisphenol A in the immature rat. Environ. Health Perspect. 106, 719-720.

Ashby, J., Odum, J., 2004. Gene expression changes in the immature rat uterus: effects of uterotrophic and subuterotrophic doses of bisphenol A. Toxicol. Sci. 82, 458-467.

Atanassova, N., McKinnell, C., Turner, K.J., Walker, M., Fisher, J.S., Morley, M., Millar, M.R., Groome, M.P, Sharpe, R.M., 2000. Comparative effects of neonatal exposure of male rats to potent and weak (environmental) estrogens on spermatogenesis at puberty and the relationship to adult testis size and fertility: evidence for stimulatory effects of low estrogens levels. Endocrinology 141, 3898-3907.

Aubert, M.L., Begeot, M., Winiger, B.P., Morel, G., Sizonenko, P.C., Dubois, P.M., 1985. Ontogeny of hypothalamic luteinizing hormonereleasing hormone $(\mathrm{GnRH})$ and pituitary GnRH receptors in fetal and neonatal rats. Endocrinology 116, $1565-1576$.

Baker, V.A., Hepburn, P.A., Kennedy, S.J., Jones, P.A., Lea, L.J., Sumpter, J.P., Ashby, J., 1999. Safety evaluation of phytosterol esters. I. Assessment of estrogenicity using a combination of in vivo and in vitro assays. Food Chem. Toxicol. 37, 13-22.

Berkey, C.S., Gardner, J.D., Frazier, A.L., Colditz, G.A., 2000. Relation of childhood diet and body size to menarche and adolescent growth in girls. Am. J. Epidemiol. 152, 446-459.

Bern, H.A., Mills, K.T., Jones, L.A., 1983. Critical period of neonatal estrogen exposure in occurrence of mammary gland abnormalities in adult mice. Proc. Soc. Exp. Biol. Med. 172, 239-242.

Bicknell, R.J., Herbison, A.E., Sumpter, J.P., 1995. Estrogenic activity of an environmentally persistent alkylphenol in the reproductive tract but not the brain of rodents. J. Steroid Biochem. Mol. Biol. 54, 7-9.

Blake, C.A., Ashiru, O.A., 1997. Disruption of rat estrous cyclicity by the environmental estrogen 4-tert-octylphenol. Proc. Soc. Exp. Biol. Med. 216, 446-451

Blake, C.A., Bookfor, F.R., 1997. Chronic administration of the environmental pollutant 4-tert-octylphenol to adult male rats interferes with the secretion of luteinizing hormone, follicle-stimulating hormone, prolactin and testosterone. Biol. Reprod. 57, $255-266$.

Blanck, H.M., Marcus, M., Tolbert, P.E., Rubin, C., Henderson, A.K., Hertzberg, V.S., Zhang, R.H., Cameron, L., 2000. Age at menarche and tanner stage in girls exposed in utero and postnatally to polybrominated biphenyl. Epidemiology 11, 641-647.

Bolt, H.M., Kappas, H., Remmer, H., 1973. Studies on the metabolism of ethynylestradiol in vitro and in vivo: the significance of 2 hydroxylation and the formation of polar products. Xenobiotica 3, 773-785.

Bolt, H.M., 1979. Metabolism of estrogens natural and synthetic. Pharmacol. Ther. 4, 155-181.

Bourguignon, J.P., Franchimont, P., 1984. Age-related increase in episodic LHRH release from rat hypothalamus in vitro. Endocrinology $114,1941-1943$

Bowe, J., Li, X.F., Sugden, D., Katzenellenbogen, J.A., Katzenellenbogen, B.S., O'Byrne, K.T., 2003. The effects of the phytoestrogen and coumestrol on gonadotrophin-releasing hormone (GnRH) mRNA expression in GT1-7 GnRH neurones. J. Neuroendocrinol. 15, $105-108$.

Bowers, J.L., Tyulmenkov, V.V., Jernigan, S.C, Klinge, C.M., 2000. Resveratrol acts as a mixed agonist/antagonist for estrogen receptor $\alpha$ and $\beta$. Endocrinology 141, 3657-3667.

Branham, W.S., Zehr, D.R., Chen, J.J., Sheehan, D.M., 1988. Uterine abnormalities in rats exposed neonatally to diethylstilbestrol, ethynylestradiol or clomiphene citrate. Toxicology 51, 201-212.

Brock, J.W., Yoshimura, Y., Barr, J.R., 2001. Measurement of bisphenol A levels in human urine. J. Expos. Anal. Environ. Epidemiol. 11, $323-328$

Bulger, W.H., Muccitelli, R.M., Kupfer, D., 1978a. Interactions of methoxychlor, methoxychlor base soluble contaminant and 2,2-bis(phydoxyphenyl)-1,1,1-trichloroethane with rat uterine estrogen receptor. J. Toxicol. Environ. Health 4, 881-893.

Bulger, W.H., Muccitelli, R.M., Kupfer, D., 1978b. Interactions of chlorinated hydrocarbon pesticides with the 8S estrogen-binding protein in rat testes. Steroids $32,165-177$

Cagen, S.Z., Waechter Jr., J.M., Diamond, S.S., Breslin, W.J., Butala, J.H., Jekat, F.W., Joiner, R.L., Shiotsuka, R.N., Veenstra, G.E., Harris, L.R., 1999. Normal reproductive organ development in CF-1 mice following prenatal exposure to bisphenol A. Toxicol. Sci. 50, 36-44.

Chiappa, S.A., Fink, G., 1977. Releasing factor and hormonal changes in the hypothalamic-pituitary-gonadotrophin and adrenocorticotrophin systems before and after birth and puberty in male, female and androgenized female rats. J. Endocrinol. 72, 211-224.

Clark, E.J., Norris, D.O., Jones, R.E., 1998. Interactions of gonadal steroids and pesticides (DDT and DDE) on gonadal duct in larval tiger salamanders Ambystoma tigrinum. Gen. Comp. Endocrinol. 109, 94-105.

Cohn, B.A., Cirillo, P.M., Wolff, M.S., Schwingl, P.J., Cohen, R.D., Sholtz, R.I., Ferrara, A., Christianson, R.E., van den Berg, B.J., Siiteri, P.K., 2003. DDT and DDE exposure in mothers and time to pregnancy in daughters. Lancet 361, 2205-2206.

Colborn, T., vom Saal, F.S., Soto, A.M., 1993. Developmental effects of endocrine disrupting chemicals in wildlife and humans. Environ. Health Perspect. 101, 378-384.

Colon, I., Caro, D., Bourdony, C.J., Rosario, O., 2000. Identification of phthalate esters in the serum of young Puerto Rican girls with premature breast development. Environ. Health Perspect. 108, 895-900.

Cooper, R.L., Chadwick, R.W., Rehnberg, G.L., Goldman, J.M., Booth, K.C., Hein, J.F., McElroy, W.K., 1989. Effects of lindane on hormonal control of reproductive function in the female rat. Toxicol. Appl. Pharmacol. 99, 384-394.

Davis, D.L., Gottlieb, M.B., Stampnitzky, J.R., 1998. Reduced rate of male to female births in several industrial countries: a sentinel health indicator? JAMA 279, 1018-1023. 
Den Hond, E., Roels, H.A., Hoppenbrouwers, K., Nawrot, T., Thijs, L., Vandermeulen, C, Winneke, G., Vanderschueren, D., Staessen, J.A., 2002. Sexual maturation in relation to polychlorinated aromatic hydrocarbons: Sharpe and Skakkebaek's hypothesis revisited. Environ. Health Perspect. 110, 771-776.

DiPaolo, D., Jones, L.A., 2000. Neonatal estradiol exposure alters mouse mammary estrogen receptor alpha expression. Int. J. Oncol. 16, 935-941.

Docke, E., Rohde, W., Lange, T., Geier, T., Dorner, G., 1981. Further studies on the hypothalamic desensitization to estrogen in immature female rats: evidence for a possible role in the control of puberty. Endocrinology 77, 1-12.

Döhler, K.D., Coquelin, A., Davis, E., Hines, M., Shryne, J.E., Gorski, R.A., 1984. Pre- and postnatal influence of testosterone and diethylstilbestrol on differentiation of the sexually dimorphic nucleus of the preoptic area in male and female rats. Brain Res. 302, $291-295$.

Drouva, S.V., Gautron, J.P, Pattou, E., Laplante, E., Kordon, C., 1986. Effects of estradiol and progesterone on immunoreactive forms of hypothalamic luteinizing hormone-releasing hormone. Neuroendocrinology 43, 32-37.

Edgren, R.A., Peterson, D.L., Jones, R.C., Nagra, C.L., Smith, H., Hughes, G.A., 1966. Biological effects of synthetic gonanes. Rec. Prog. Horm. Res. 22, 305-349.

Ferguson, S.A., Scallet, A.C., Flynn, K.M., Meredith, J.M., Schwetz, B.A., 2000. Developmental neurotoxicity of endocrine disrupters: focus on estrogens. Neurotoxicology 21, 947-956

Ford, H., Ebling, F.J., 2000. Glutamatergic regulation of gonadotrophin-releasing hormone mRNA level during development in the mouse. J. Neuroendocrinol. 12, 1027-1033.

Freyberger, A., Hartmann, E., Hildebrand, H., Krotlinger, F., 2001. Differential response of immature rat uterine tissue to ethynylestradiol and the red wine constituent resveratrol. Arch. Toxicol. 74, 709-715.

Gallo, D., Cantelmo, F., Distefano, M., Ferlini, C., Zannoni, C., Riva, G.F., Morazzoni, P., Bombeardelli, E., Mancuso, S., Scambia, G., 1999. Reproductive effects of dietary soy in female Wistar rats. Food Chem. Toxicol. 37, 493-502.

Gehm, B.D., McAndrews, J.M., Chien, P.Y., Jameson, J.L., 1997. Resveratrol, a polyphenolic compound found in grapes and wine, is an agonist for the estrogen receptor. Proc. Natl. Acad. Sci. U.S.A. 94, 14138-14143.

Gladen, B.C., Ragan, N.B., Rogan, W.J., 2000. Pubertal growth and development, and prenatal and lactational exposure to polychlorinated biphenyls and dichlorodiphenyldichloroethene. J. Pediatr. 136, 490-496.

Gore, A.C., Wu, T.J., Rosenberg, J.J., Roberts, J.L., 1996. Gonadotrophin-releasing hormone and NMDA receptor gene expression and colocalization change during puberty in female rats. J. Neurosci. 16, 5281-5289.

Gore, A.C., Roberts, J.L., Gibson, M.J., 1999. Mechanisms for the regulation of gonadotrophin-releasing hormone gene expression in the developing mouse. Endocrinology 140, 2280-2287.

Gore, A.C., 2002. Organochlorine pesticides directly regulate gonadotrophin-releasing hormone gene expression and biosynthesis in the GT1-7 hypothalamic cell line. Mol. Cell. Endocrinol. 192, 157-170.

Gore, A.C., Wu, T.J., Oung, T., Lee, J.B., Woller, M.J., 2002. A novel mechanism for endocrine-disrupting effects of polychlorinated biphenyls: direct effects on gonadotrophin-releasing hormone neurones. J. Neuroendocrinol. 14, 814-823.

Gould, J.C., Leonard, L.S., Maness, S.C., Wagner, B.L., Conner, K., Zacharewski, T., Safe, S., McDonnell, D.P., Gaido, K.W., 1998. Bisphenol A interacts with the estrogen receptor $\alpha$ in a distinct manner from estradiol. Mol. Cell. Endocrinol. 142, $203-214$.

Gray Jr., L.E., Ostby, J., Sigmon, R., Ferrell, J., Rehnberg, G., Linder, R., Cooper, R., Goldman, J., Laskey, J., 1988. The development of a protocol to assess reproductive effects of toxicants in the rat. Reprod. Toxicol. 2, 281-287.

Gray Jr., L.E., Ostby, J., Ferrell, J., Rehnberg, G., Linder, R., Cooper, R., Goldman, J., Slott, V., Laskey, J., 1989. A dose-response analysis of methoxychlor-induced alterations of reproductive development and function in the rat. Fundam. Appl. Toxicol. 12, 92-108.

Gray Jr., L.E., 1998. Tiered screening and testing strategy for xenoestrogens and antiandrogens. Toxicol. Lett. 102-103, 677-680.

Gray Jr., L.E., Ostby, J., 1998. Effects of pesticides and toxic substances on behavioral and morphological reproductive development: endocrine versus nonendocrine mechanisms. Toxicol. Ind. Health 14, 159-184

Grumbach, M.M., Styne, D.M., 2003. Puberty: ontogeny, neuroendocrinology, physiology and disorders. In: Wilson, J.D., Foster, D.W., Kronenberg, H.M., Larsen, PR. (Eds.), William's Textbook of Endocrinology. WB Saunders, Philadelphia, pp. 1509-1625.

Guo, Y.L., Lambert, G.H., Hsu, C.C., Hsu, M.M., 2004. Yucheng: health effects of prenatal exposure to polychlorinated biphenyls and dibenzofurans. Int. Arch. Occup. Environ. Health 77, 153-158.

Gutendorf, B., Westendorf, J., 2001. Comparison of an array of in vitro assays for the assessment of the estrogenic potential of natural and synthetic estrogens, phytoestrogens and xenoestrogens. Toxicology 166, 79-89.

Hailing, A., Forsberg, J.G., 1993. Acute and permanent growth effects in the mouse uterus after neonatal treatment with estrogens. Reprod. Toxicol. 7, 137-153.

Hama, Y., Uematsu, M., Sakurai, Y., Kusano, S., 2001. Sex ratio in the offspring of male radiologists. Acad. Radiol. 8, 421-424

Haney, A.F., Newbold, R.R., McLachlan, J.A., 1984. Prenatal diethylstilbestrol exposure in the mouse: effects on ovarian histology and steroidogenesis in vitro. Biol. Reprod. 30, 471-478.

Hany, J., Lilienthal, H., Sarasin, A., Roth-Harer, A., Fastabend, A., Dunemann, L., Lichtensteiger, W., Winneke, G., 1999. Developmental exposure of rats to a reconstituted PCB mixture or aroclor 1254: effects on organ weights, aromatase activity, sex hormone levels and sweet preference behavior. Toxicol. Appl. Pharmacol. 158, 231-243. 
Published in: Molecular \& Cellular Endocrinology (2006), vol. 254-255, pp. 187-201.

Status: Postprint (Author's version)

Harris, G.C., Levine, J.E., 2003. Pubertal acceleration of pulsatile gonadotrophin-releasing hormone release in male rats as revealed by microdialysis. Endocrinology 144, 163-171

Herbst, A.L., Anderson, D., 1990. Clear cell adenocarcinoma of the vagina and cervix secondary to intrauterine exposure to diethylstilbestrol. Semin. Surg. Oncol. 6, 343-346.

Hiroi, H., Tsutsumi, O., Momoeda, M., Takai, Y., Osuga, Y., Taketani, Y., 1999. Differential interactions of bisphenol A and 17 $\beta$-estradiol with estrogen receptor $\alpha(E R \alpha)$ and ER $\beta$. Endocr. J. 46, 773-778.

Holmes, P., Rumsby, P., Harrison, P.T., 2004. Endocrine disrupters and menopausal health. J. Br. Menopause Soc. 10, 54-59.

Hopert, A.C., Beyer, A., Frank, K., Strunck, E., Wunsche, W., Vollmer, G., 1998. Characterization of estrogenicity of phytoestrogens in an endometrial-derived experimental model. Environ. Health Perspect. 106, 581-586.

Howdeshell, K.L., Hotchkiss, A.K., Thayer, K.A., Vandenbergh, J.G., vom Saal, F.S., 1999. Exposure to bisphenol A advances puberty. Nature 401, 763-764

Huseby, R.A., Thurlow, S., 1982. Effects of prenatal exposure of mice to "low-dose" diethylstilbestrol and the developmental adenomyosis associated with evidence of hyperprolactinemia. Am. J. Obstet. Gynecol. 144, 939-949.

Ikeda, Y., Nagai, A., Ikeda, M.A., Hayashi, S., 2001. Neonatal estrogen exposure inhibits steroidogenesis in the developing rat ovary. Dev. Dyn. 221, 443-453.

Jefferson, W.N., Newbold, R.R., 2000. Potential endocrine-modulating effects of various phytoestrogens in the diet. Nutrition 16, 658-662.

Jefferson, W.N., Padilla-Banks, E., Newbold, R.R., 2005. Adverse effects on female development and reproduction in CD-1 mice following neonatal exposure to the phytoestrogen genistein at environmentally relevant doses. Biol. Reprod. 73, 798-806.

Kapoor, J.R, Metcalf, R.L., Nystrom, R.F., Sangha, G.K., 1970. Comparative metabolism of methoxychlor, methiochlor and DDT in mouse, insects and in a model ecosystem. J. Agric. Food Chem. 18, 1145-1152.

Kato, H., Ota, T., Furuhashi, T., Ohta, Y., Iguchi, T., 2003. Changes in reproductive organs of female rats treated with bisphenol A during the neonatal period. Reprod. Toxicol. 17, 283-288.

Kelce, W.R., Sone, C.R., Laws, S.C., Gray, L.E., Kemppainen, J.A., Wilson, E.A., 1995. Persistent DDT metabolite p,p'-DDH is a potent androgen receptor antagonist. Nature 375, 581-585.

Key, T., Reeves, G., 1994. Organochlorines in the environment and breast cancer. Br. Med. J. 308, 1520-1521.

Kim, H.S., Shin, J.H., Moon, H.J., Kang, I.H., Kim, T.S., Kim, I.Y., Seok, J.H., Pyo, M.Y., Han, S.Y., 2002. Comparative estrogenic effects of $p$-nonylphenol by 3-day uterotrophic assay and female pubertal onset assay. Reprod. Toxicol. 16, 259-268.

Klaassen, C.D., Eaton, D.L., 1991. Principles of toxicology. In: Amdur, M.O., Doull, J., Klaassen, C.D. (Eds.), Casarett and Doull's Toxicology, the Basic Science of Poisons. McGraw-Hill Inc., New York, pp. 12-49.

Korach, K.S., Metzler, M., McLachlan, J.A., 1978. Estrogenic activity in vivo and in vitro of some diethylstilbestrol metabolites and analogs. Proc. Natl. Acad. Sci. U.S.A. 75, 468-471

Krishnan, A.V., Stathis, P., Permuth, S.F., Tokes, L., Feldman, D., 1993. Bisphenol A: an estrogenic substance is released from polycarbonate flasks during autoclaving. Endocrinology 132, 2279-2286.

Krstevska-Konstantinova, M., Charlier, C., Craen, M., Du Caju, M., Heinrichs, C, de Beaufort, C, Plomteux, G., Bourguignon, J.P, 2001. Sexual precocity after immigration from developing countries to Belgium: evidence of previous exposure to organochlorine pesticides. Hum. Reprod. 16, 1020-1026.

Kubo, K., Arai, O., Omura, M., Watanabe, R., Ogata, R., Aou, S., 2003. Low-dose effects of bisphenol A on sexual differentiation of the brain and behavior in rats. Neurosci. Res. $45,345-356$

Kuhl, A.J., Manning, S., Brouwer, M., 2005. Brain aromatase in Japanese medaka (Oryzias latipes): molecular characterization and role in xenoestrogen-induced sex reversal. J. Steroid Biochem. Mol. Biol. 96, 67-77.

Kwon, A., Stedman, D.B., Elswick, B.A., Cattley, R.C., Welsch, F, 2000. Pubertal development and reproductive functions of Cr1: CDBR Sprague-Dawley rats exposed to bisphenol A during prenatal and postnatal development. Toxicol. Sci. 55, 399-406.

Laws, S.C., Carey, S.A., Ferrell, J.M., Bodman, G.J., Cooper, R.L., 2000. Estrogenic activity of octylphenol, nonylphenol, bisphenol A and methoxychlor in rats. Toxicol. Sci. 54, 154-167.

Levine, J.E., 1997. New concepts of the neuroendocrine regulation of gonadotrophin surges in rats. Biol. Reprod. 56, 293-302.

Levy, J.R., Faber, K.A., Ayyash, L., Hughes Jr., C.L., 1995. The effect of prenatal exposure to the phytoestrogen genistein on sexual differentiation in rats. Proc. Soc. Exp. Biol. Med. 208, 60-66.

Li, X., Johnson, D.C., Rozman, K.K., 1995. Reproductive effects of 2,3,7,8-tetrachlorodibenzo-p-dioxin (TCDD) in female rats: ovulation, hormonal regulation and possible mechanism(s). Toxicol. Appl. Pharmacol. 133, 321-327.

Li, X., Johnson, D.C., Rozman, K.K., 1997. 2,3,7,8-tetrachlorodibenzo-p-dioxin (TCDD) increases release of luteinizing hormone and follicle-stimulating hormone from the pituitary of immature female rats in vivo and in vitro. Toxicol. Appl. Pharmacol. 142, 264-269.

Markey, C.M., Luque, E.H., Munoz-de-Toro, M., Sonnenschein, C., Soto, A.M., 2001. In utero exposure to bisphenol A alters the development and tissue organization of the mouse mammary gland. Biol. Reprod. 65, 1215-1223.

Marshall, E., 1993. Search for a killer: focus shifts from fat to hormones. Science 259, 618-621.

Martin, P.M., Horwitz, K.B., Ryan, D.S., McGuire, W.L., 1978. Phytoestrogen interaction with estrogen receptors in human breast cancer cells. Endocrinology 103, 1860-1897. 
Marty, M.S., Crissman, J.W., Carney, E.W., 1999. Evaluation of the EDSTAC female pubertal assay in CD rats using $17 \beta$-estradiol, steroid biosynthesis inhibitors and a thyroid inhibitor. Toxicol. Sci. 52, 269-277.

Massart, F., Seppia, P., Pardi, D., Lucchesi, S., Meossi, C., Gagliardi, L., Liguori, R., Fiore, L., Federico, G., Saggese, G., 2005. High incidence of central precocious puberty in a bounded geographic area of Northwest Tuscany: an estrogen disrupter epidemic? Gynecol. Endocrinol. 20, 92-98.

Matagne, V., Rasier, G., Lebrethon, M.C., Gerard, A., Bourguignon, J.P., 2004. Estradiol stimulation of pulsatile gonadotrophin-releasing hormone secretion in vitro: correlation with perinatal exposure to sex steroids and induction of sexual precocity in vivo. Endocrinology 145 , $2775-2783$

McGarvey, C., Cates, P.A., Brooks, A., Swanson, I.A., Milligan, S.R., Coen, C.W., O'Byrne, K.T., 2001. Phytoestrogens and gonadotrophinreleasing hormone pulse generator activity and pituitary luteinizing hormone release in the rat. Endocrinology 142, $1202-1208$.

McKee, R.H., Toxicology Research Task Group, Phthalate Esters Panel American Chemistry Council, 2004. Phthalate exposure and early thelarche. Environ. Health Perspect. 112, 541-543.

McLachlan, J.A., Newbold, R.R., Shah, H.C., Hogan, M.D., Dixon, R.L., 1982. Reduced fertility in female mice exposed transplacentally to diethylstilbestrol (DES). Fertil. Steril. 38, 364-371.

McLachlan, J.A., Newbold, R.R., 1987. Estrogens and development. Environ. Health Perspect. 75, 25-27.

Medlock, K.L., Branham, W.S., Sheehan, D.M., 1995. Effects of coumestrol and equol on the developing reproductive tract of the rat. Proc. Soc. Exp. Biol. Med. 208, 67-71.

Merino, M.J., 1991. Vaginal cancer: the role of infectious and environmental factors. Am. J. Obstet. Gynecol. 165, $1255-1262$.

Miodini, P., Fioravanti, L., Di Fronzo, G., Cappelletti, V., 1999. The two phytoestrogens genistein and quercetin exert different effects on estrogen receptor function. Br. J. Cancer 80, 1150-1155.

Mocarelli, P., Gerthoux, P.M., Ferrari, E., Patterson Jr., D.G., Kieszak, S.M., Brambilla, P., 2000. Paternal concentrations of dioxin and sex ratio of offspring. Lancet 355, 1858-1863.

Mol, N.M., Sorensen, N., Weihe, P., Andersson, A.M., Jorgensen, N., Skakkebaek, N.E., Keiding, N., Grandjean, P., 2002. Spermaturia and serum hormone concentrations at the age of puberty in boys prenatally exposed to polychlorinated biphenyls. Eur. J. Endocrinol. 146, 357363.

Moore Jr., J.P, Wray, S., 2000. Luteinizing hormone-releasing hormone (LHRH) biosynthesis and secretion in embryonic LHRH. Endocrinology 141, 4486-4495.

Mori, T., Bern, H.A., Mills, K.T., Young, P.N., 1976. Long-term effects of neonatal steroids exposure on mammary gland development and tumorigenesis in mice. J. Natl. Cancer Inst. 57, 1057-1062.

Munoz-de-Toro, M., Markey, C.M., Wadia, P.R., Luque, E.H., Rubin, B.S., Sonnenschein, C., Soto, A.M., 2005. Perinatal exposure to bisphenol A alters peripubertal mammary gland development in mice. Endocrinology 146, 4147-4188.

Naftolin, F., 1994. Brain aromatization of androgens. J. Reprod. Med. 39, 257-261.

Nagao, T., Ohta, R., Marumo, H., Shindo, T., Yoshimura, S., Ono, H., 2000. Effect of butyl benzyl phthalate in Sprague-Dawley rats after gavage administeration: a two-generation reproductive study. Reprod. Toxicol. 14, 513-532.

Nass, T.E., Matt, D.W., Judd, H.L., Lu, J.K.H., 1984. Prepubertal treatment with estrogen or testosterone precipitates the loss of regular estrous cyclicity and normal gonadotrophin secretion in adult female rats. Biol. Reprod. 31, 723-731.

Nelson, K., Pavlik, E.J., van Nagell Jr., J.R., Hanson, M.B., Donaldson, E.S., Flanigan, R.C., 1984. Estrogenicity of coumestrol in the mouse: fluorescence detection of interaction with estrogen receptors. Biochemistry 23, 2565-2572.

Newbold, R.R., Bullock, B.L., McLachlan, J.A., 1983. Exposure to diethylstilbestrol during pregnancy permanent alters the ovary and oviduct. Biol. Reprod. 28, 735-744

Newbold, R.R., Hanson, R.B., Jefferson, W.N., Bullock, B.L., Haseman, J., McLachlan, J.A., 1998. Increased tumors but uncompromised fertility in the female descendants of mice exposed developmentally to diethylstilbestrol. Carcinogenesis 19, 1655-1663.

Odum, J., Lefevre, P.A., Tittensor, S., Paton, D., Routledge, E.J., Beresford, N.A., Sumpter, J.R, Ashby, J., 1997. The rodent uterotrophic assay: critical protocol features, studies with nonylphenols and comparison with a yeast estrogenicity assay. Regul. Toxicol. Pharmacol. 25, 176-188.

Ohtake, E., Takeyama, K.I., Matsumoto, T., Kitagawa, H., Yamamoto, Y., Nohara, K., Tohyama, C., Krust, A., Mimura, J., Chambon, P., Yanagisawa, J., Fujii-Kuriyama, Y., Kato, S., 2003. Modulation of estrogen receptor signalling by association with the activated dioxin receptor. Nature 423, 545-550.

Ojeda, S.R., Urbanski, H.E., Katz, K.H., Costa, M.E., 1986. Activation of estradiol-positive feedback at puberty: estradiol sensitizes the LHRH-releasing system at two different biochemical steps. Neuroendocrinology 43, 259-265.

Ojeda, S.R., Terasawa, E., 2002. Neuroendocrine regulation of puberty. Horm. Brain Behav. 75, 589-659.

Palanza, P., Parmigiani, S., vom Saal, E.S., 2001. Effects of prenatal exposure to low doses of diethylstilbestrol, o,p'-DDT and methoxychlor on postnatal growth and neurobehavioral development in male and female mice. Horm. Behav. 40, 252-265.

Parent, A.S., Teilmann, G., Juul, A., Skakkebaek, N.E., Toppari, J., Bourguignon, J.R., 2003. The timing of normal puberty and the age limits of sexual precocity: variations around the world, secular trends and changes after migration. Endocr. Rev. 24, 668-693.

Parent, A.S., Lebrethon, M.C., Gerard, A., Bourguignon, J.R, 2005. Factors accounting for perinatal occurrence of pulsatile gonadotrophinreleasing hormone secretion in vitro in rats. Biol. Reprod. 72, 143-149. 
Published in: Molecular \& Cellular Endocrinology (2006), vol. 254-255, pp. 187-201.

Status: Postprint (Author's version)

Partsch, C.J., Sippel, W.G., 2001. Pathogenesis and epidemiology of precocious puberty. Effects of exogenous estrogens. Hum. Reprod. Update 7, 292-302.

Petroff, B.K., Croutch, C.R., Hunter, D.M., Wierman, M.E., Gao, X., 2003. 2,3,7,8-tetrachlorodibenzo-p-dioxin (TCDD) stimulates gonadotrophin secretion in the immature female Sprague-Dawley rat through a pentobarbital- and estradiol-sensitive mechanism but does not alter gonadotrophin-releasing hormone $(\mathrm{GnRH})$ secretion by immortalized GnRH neurons in vitro. Biol. Reprod. 68, $2100-2106$.

Potashnik, G., Goldsmith, J., Insler, V., 1984. Dibromochloropropane-induced reduction of the sex ratio in man. Andrologia 16, $213-218$.

Ramirez, V.D., Sawyer, C.H., 1965. Advancement of puberty in the female rat by estrogen. Endocrinology 76, 1158-1168.

Rasier, G., Matagne, V., Parent, A.S., Gerard, A., Lebrethon, M.C., Bourguignon, J.P, 2005. Estradiol and dichlorodiphenyltrichloroethane administration in infantile female rats: similar stimulation of gonadotrophin-releasing hormone secretion in vitro and sexual maturation in vivo through different receptor mechanisms. In: Proceedings of the 87th Annual Meeting of the Endocrine Society. San Diego: Endocrine Society, p. 190

Rogan, W.J., Gladen, B.J., Guo, Y.L.L., Hsu, C.C., 1999. Sex ratio after exposure to dioxin-like chemicals in Taiwan. Lancet 353, $206-207$.

Roy, D., Angelini, N.L., Belsham, D.D., 1999. Estrogen directly represses gonadotrophin-releasing hormone (GnRH) gene expression in estrogen receptor alpha (ER $\alpha)$ - and ER $\beta$-expressing GT1-7 GnRH neurons. Endocrinology 140, 5045-5053.

Rubin, B.L., Murray, M.K., Damassa, D.A., King, J.C., Soto, A.M., 2001. Perinatal exposure to low doses of bisphenol A affects body weight, patterns of estrous cyclicity and plasma LH levels. Environ. Health Perspect. 109, 675-680.

Saiyed, H., Dewan, A., Bhatnagar, V., Shenoy, U., Shenoy, R., Rajmohan, H., Patel, K., Kashyap, R., Kulkarni, P., Rajan, B., Lakkad, B., 2003. Effect of endosulfan on male reproductive development. Environ. Health Perspect. 111, 1958-1962.

Sakamoto, M., Nakano, A., Akagi, H., 2001. Declining Minamata male birth ratio associated with increased male fetal death due to heavy methylmercury pollution. Environ. Res. 87, 92-98.

Sakurai, K., Mori, C., 2000. Fetal exposure to endocrine disrupters. Nippon Rinsho 58, 2508-2513.

Salazar, V., Castillo, C., Ariznavarreta, C., Campon, R., Tresguerres, J.A., 2004. Effect of oral intake of dibutyl phthalate on reproductive parameters of Long-Evans rats and prepubertal development of their offspring. Toxicology 205, 131-137.

Schrager, S., Potter, B.E., 2004. Diethylstilbestrol exposure. Am. Fam. Physician 69, 2395-2400.

Selevan, S.G., Rice, D.C., Hogan, K.A., Euling, S.Y., Pfahles-Hutchens, A., Bethel, J., 2003. Blood lead concentration and delayed puberty in girls. New Engl. J. Med. 348, 1527-1536.

Sisk, C.L., Richardson, H.N., Chappell, P.E., Levine, J.E., 2001. In vivo gonadotrophin-releasing hormone secretion in female rats during peripubertal development and on proestrus. Endocrinology 142, 2929-2936.

Soto, A.M., Chung, K.L., Sonnenschein, C., 1994. The pesticides endosulfan, toxaphene and dieldrin have estrogenic effects on human estrogensensitive cells. Environ. Health Perspect. 102, 380-383.

Soto, A.M., Fernandez, M.F., Luizzi, M.F., Oles Karasko, A.S., Sonnenschein, C., 1997. Developing a marker of exposure to xenoestrogen mixtures in human serum. Environ. Health Perspect. 105, 647-654.

Staessen, J.A., Nawrot, T., Hond, E.D., Thijs, L., Fagard, R., Hoppenbrouwers, K., Koppen, G., Nelen, V., Schoeters, G., Vanderschueren, D., Van Hecke, E., Verschaeve, L., Vlietinck, R., Roels, H.A., 2001. Renal function, cytogenetic measurements and sexual development in adolescents in relation to environmental pollutants: a feasibility study of biomarkers. Lancet 357, 1660-1669.

Takeyoshi, M., Yamasaki, K., Sawaki, M., Nakai, M., Noda, S., Takatsuki, M., 2002. The efficacy of endocrine disruptor screening tests in detecting antiestrogenic effects downstream of receptor-ligand interactions. Toxicol. Lett. 126, 91-98.

Tarttelin, M.F., Gorski, R.A., 1988. Postnatal influence of diethylstilbestrol on the differentiation of the sexually dimorphic nucleus in the rat is as effective as perinatal treatment. Brain Res. 456, 271-274.

Terasawa, E., 2001. Luteinizing hormone-releasing hormone (LHRH) neurons: mechanism of pulsatile LHRH release. Vitam. Horm. 63, 91129.

Tomooka, Y., Bern, H.A., 1982. Growth of mouse mammary glands after neonatal sex hormone treatment. J. Natl. Cancer Inst. 69, 13471352

Toppari, J., Larsen, J.C., Christiansen, P., Giwercman, A., Grandjean, P., Guillette Jr., L.G., Jegou, B., Jensen, T.K., Jouannet, P., Keiding, N., Leffers, H., McLachlan, J.A., Meyer, O., Muller, J., Rajpert-De meyts, E., Scheike, T., Sharpe, R., Sumpter, J., Skakkebaek, N.E., 1996. Male reproductive health and environmental xenoestrogens. Environ. Health Perspect. 104, 741-803.

Toppari, J., Skakkebaek, N.E., 1998. Sexual differentiation and environmental endocrine disrupters. Bailliere's Clin. Endocrinol. Metab. 12, 143-156.

Toppari, J., 2002. Environmental endocrine disrupters and disorders of sexual differentiation. Semin. Reprod. Med. 20, 305-312.

Vancutsem, P.M., Roessler, M.L., 1997. Neonatal treatment with tamoxifen causes immediate alterations of the sexually dimorphic nucleus of the preoptic area and medial preoptic area in male rats. Teratology 56, 220-228.

Vasiliu, O., Muttinemi, J., Karmaus, W., 2004. In utero exposure to organochlorines and age at menarche. Hum. Reprod. 19, 1506-1512.

Warner, M.R., 1976. Effect of various doses of estrogen to BALB/c Crg1 neonatal female mice on mammary growth and branching at 5 weeks of age. Cell. Tissue Kinet. 9, 429-438.

Warner, M., Samuels, S., Mocarelli, P., Gerthoux, P.M., Needham, L., Patterson Jr., D.G., Eskenazi, B., 2004. Serum dioxin concentrations and age at menarche. Environ. Health Perspect. 112, 1289-1292. 
Published in: Molecular \& Cellular Endocrinology (2006), vol. 254-255, pp. 187-201.

Status: Postprint (Author's version)

Wetsel, W.C., Mellon, P.L., Weiner, R.I., Negro-Vilar, A., 1991. Metabolism of pro-luteinizing hormone-releasing hormone in immortalized hypothalamic neurons. Endocrinology 129, 1584-1595.

Whitten, P.L., Naftolin, F., 1992. Effects of a phytoestrogen diet on estrogen-dependent reproductive processes in immature female rats. Steroids 57, 56-61.

Wormke, M., Stoner, M., Saville, B., Walker, K., Abdelrahim, M., Burghardt, R., Safe, S., 2003. The aryl hydrocarbon receptor mediates degradation of estrogen receptor alpha through activation of proteasomes. Mol. Cell. Biol. 23, 1843-1855.

Wu, T., Buck, G.M., Mendola, P., 2003. Blood lead levels and sexual maturation in U.S. girls: The Third National Health and Nutrition Examination Survey, 1988-1994. Environ. Health Perspect. 111, 737-741.

Zwain, I.H., Arroyo, A., Amato, P., Yen, S.S., 2002. A role for hypothalamic astrocytes in dehydroepiandrosterone and estradiol regulation of gonadotrophin-releasing hormone $(\mathrm{GnRH})$ release by GnRH neurons. Neuroendocrinology 75, 375-383. 